\title{
EVALUATION OF EDUCATION SYSTEM DURING COVID-19 TOWARD STUDENTS' PSYCHOLOGY
}

\author{
Afriana \\ Universitas Putera Batam (UPB), Batam, Kepri, Indonesia \\ afrianaupb@gmail.com ${ }^{1}$, afriana@puterabatam.ac.id.
}

\begin{abstract}
The Covid-19 virus disease affects the entire world, including the education system and its impact on students' psychology. The goal of this study is to learn how the education system transitioned from offline or face-to-face teaching learning to online teaching-learning mode at Putera Batam University for the teaching-learning process and semester exams via online during COVID-19. In this study, the descriptive qualitative approach was used to discover students' psychology in online learning. In order to overcome these issues, the purpose of this study is to provide a comprehensive picture of online teaching and learning activities taking place during the lockdown period, including the link between the change management process and online teaching and learning processes in the education system in the midst of the COVID-19 outbreak. Ongoing disruption and resumption of educational activities and discourse as normal procedures in the education system. The data were analyzed using Wile (Syahputri et al., 2020) and Miles Huberman and Saldana (2014). They were 110 students as respondents (B.Miles et al., 2014). The result found that students fatigued $100 \%$, they felt headache, tired, shoulder sore $85 \%$, demotivation $21 \%$, withdrawal, and procrastination $70 \%$, bad time management about $76 \%$, and Feeling Isolated $85 \%$ and Uncertainty to what the lecturer/friends explain during the class $75 \%$.
\end{abstract}

Keywords: COVID-19, education system, , virtual classes, students' psychology.

\section{INTRODUCTION}

The Coronavirus (Covid-19) outbreak impacts the mental health system, followed by the education system to various regions in Indonesia. Online system learning is one of the solutions to keep teaching tasks between the lecturers and the students. English Program is one of the programs which have practical teaching. Meaning, it is pretty challenging for the lecturers to transfer the knowledge by online method. This pandemic has made us prioritize the health issue (to suppress the spreading of Covid-19) and the quality of the teaching process mainly, how we can make sure students understood the practical learning in the pandemic situation. We need to apply the best method which considers the health issue and the applicable teaching 
quality. As we know, the problem of this pandemic is uncertainty, and we do not know when it will be the end. Although vaccines have been distributed to the people, we still hear and see the new mutation infect many people, and even mortality cases arise, especially in Indonesia (Gugus Tugas Percepatan Penanganan COVID-19 RI, 2020) (Indonesia Covid-19 Handling Task Force, 2021) (Ramatillah \& Isnaini, 2021).

The transformation of the teaching method forces the students to adapt quickly to the new teaching method. Many factors contribute to adaptation, such as the tool and the speed to receive knowledge transfer. Some students need to adjust their needs. Previously, they will come to the library campus to use the laptop or internet, but now, they must have their computer to attend the online lecturers. Not only that, they need to ensure they have the internet to join with every section of online learning. Besides that, they need to focus and absorb the transfer knowledge from their lecturers to ensure they are not left behind. All these things have an impact on their psychology. Another problem arises from the mental health issue. Online learning makes many students experience fatigue because the learning system is absolute screen time, more focus and high motivation are needed. Universities need to reinvent their learning environment so that digitalization thrives and complements faculty-student relationships (OECD, 2020).

\section{LITERATURE REVIEW}

The pandemic has a significant financial impact, particularly on students from low-income families.
Financial stress, while unrelated to social distancing, has been found to pose a serious threat to mental wellbeing. Students from low-income families must work to meet their needs in online classes. We are all aware that internet access is required for online classes. They must purchase it. Furthermore, they frequently lack access to devices such as mobile phones, laptop computers, and other devices that facilitate online learning. In fact, the government has moved the education system to a digital platform. These are inaccessible to students, particularly those who are impoverished and live in a variety of economic hardships. Online education appears to be a challenge for students whose families are dealing with a variety of financial issues. Even if they are able to survive it, they will most likely experience mental strain as a result of achieving it because they have other basic needs that must be met (Joseph, 2020).

Students who take online classes have significantly more screen time. This causes an anomaly in their routine, which can manifest itself holistically in their mental well-being. Students may encounter seven difficulties while taking online classes. First, they were exhausted. Fatigue is more common than we think. It occurs without warning and leads to mental health problems. Second, they frequently experience headaches or other types of physical pain. Third, they become unmotivated to complete tasks assigned to them by their teachers. Fourth, they have a tendency to avoid and procrastinate on their tasks. Fifth, they become careless with time management, which includes other routine activities like eating, sleeping, 
and doing household chores. Sixth, they create a sense of isolation because they do not interact with other people or make new friends. Finally, they barely understand what the lecturer or their classmates are saying during online classes. This is because the situation is very different from person-to-person dialogue, in which they can read gestures, voice pitch and intonation, facial expressions, and other features that can help them understand the learning materials (Wiles, 2020). (Irawan et al., 2020)

\section{RESEARCH METHOD}

The descriptive qualitative approach was used to conduct this study. When a straightforward portrayal of a situation is desired, this approach should be used. It is a methodology that is extremely useful when researchers need to know who was included, what was included, as well as where and how things occurred in terms of functions (Creswell, 2013). The study included 110 students from Putera Batam University in Batam, Riau Island, Indonesia. The respondents voluntarily completed a set of closed-ended questionnaires developed by Wiles based on the increased-screen shortcomings criteria (2020).

To facilitate the response process and avoid misinterpretation, the questionnaire set was distributed via Google form in Indonesian, and respondents were asked to answer 'yes' or 'no'. The data was then analyzed using interactive analysis, as suggested by Miles, Huberman, and Saldana (2014). Data condensation, data display, and conclusion drawing are the steps. The process of selecting, focusing, simplifying, abstracting, and transforming raw data from a data set is referred to as data condensation.

Data display that includes data analysis that is taking place in the natural setting to allow researchers to draw conclusions. Finally, there is data verification, in which the researchers use the results of the previous steps as well as other theories to form conclusions. The questionnaire items are shown in Table 1. , the author used an instrument that is set and produced by (Wiles, 2020). (Hasan et al., 2020)

Table 1. Questionnaire of Effect of Online Screen

\begin{tabular}{ll}
\hline No. & $\begin{array}{l}\text { Effects of Online } \\
\text { Screen }\end{array}$ \\
$\mathbf{1}$ & $\begin{array}{l}\text { Response } \\
\text { Fatigue }\end{array}$ \\
$\mathbf{2}$ & $\begin{array}{l}\text { Headache / other } \\
\text { physical pain }\end{array}$ \\
$\mathbf{3}$ & $\begin{array}{l}\text { Demotivation } \\
\mathbf{4}\end{array}$ \\
Withdrawal and \\
procrastination \\
$\mathbf{5}$ & $\begin{array}{l}\text { Bad } \\
\text { management }\end{array}$ \\
$\mathbf{6}$ & $\begin{array}{l}\text { Feeling Isolated } \\
\mathbf{7}\end{array}$ \\
& $\begin{array}{l}\text { Uncertainty to what } \\
\text { the lecturer/friend } \\
\text { explain during the } \\
\text { class }\end{array}$ \\
\hline instrument that is set and produced by (Wiles, 2020)
\end{tabular}

Table above proposed by wiles 2020, there are 7 effects of Online Screen that caused by online teaching learning. The first effect is fatigue, second Headache / other physical pain, third is Demotivation, fourth is Withdrawal and procrastination, fifth is Bad time management, sixth is Feeling Isolated and the last is Uncertainty to what the lecturer/friend explain during the class. Based on these effects of online screen, it can be seen that the 
students feel when they do online learning teaching.

\section{RESULT AND DISCUSSION}

Following the completion of the data collection process, the data underwent the consideration process. The data set condensed information about the respondent's gender, academic year, and average screen time. This study does not specifically include these variables. As a result, only data related to the mental effects of increased screen time during online learning in the COVID-19 pandemic were included. As a result, Figure 1 depicts the data display. The set questionnaire set in this image consists of seven items. These items were tested for validity using Pearson product Moment ( $r$ ), and they are all valid $\left(\alpha=0.05, r_{x y}=0.926>r\right.$ table $=0.754)$. For reliability, Alpha Cronbach's test was used, and the value was $r=0.811$.

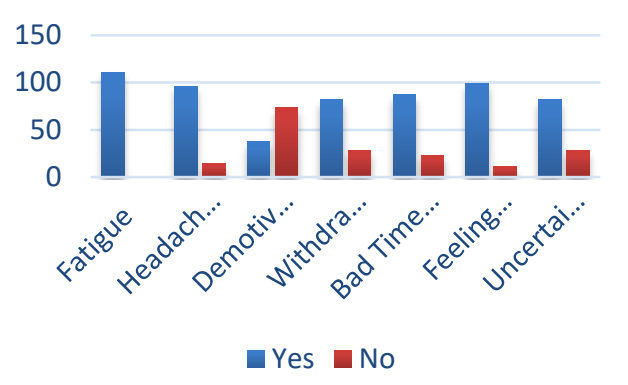

Figure 1. Result on Questionnaire of Effect of Online Screen

Based on the figure 1 above, there are 110 respondents filled the questionnaire proposed by Wiles. From collection data was done, there are 110 of the students who answered yes that they were Fatigue, 96 of the students who answered yes that they were Headache/Physical Pain, 37 of the students who answered yes that they were Demotivation, 82 of the students who answered yes that they were withdrawal and procrastination, 87 of the students who answered yes that they were bad Time management, 99 of the students who answered yes that they were Feeling Isolated, and 82 of the students who answered yes that they were uncertainty to what the lecturer/friends explain during the class.

In conclusion, the students felt Fatigue $100 \%$ of the time, Headache/Physical Pain $87 \%$ of the time, Demotivation $34 \%$ of the time, Withdrawal and procrastination $75 \%$ of the time, Bad Time Management 79 percent of the time, Feeling Isolated $90 \%$ of the time, and Uncertainty about what the lecturer/friends explain during class $75 \%$ of the time.

\section{CONCLUSION}

It can be concluded that, of the seven effects derived from increased screen time as adapted by Wiles (2020), five major effects are confirmed by students at Putera Batam University, Batam, Riau Island, Indonesia. The consequences include fatigue, headaches, and other physical pain, poor time management, a sense of isolation, and uncertainty about what the lecturer or classmates explain during class. The other two factors, demotivation and procrastination, are not the result of the respondents' excessive screen time.

They can still control their motivation for learning, and they do not procrastinate on the lecturer's assignments. The study's implication is that every educational level should have a mental health unit to assist students with the aforementioned psychological burdens. It is regarded as necessary because the online learning model is expected to continue for a longer period of time. Aside from students' mental and physical health, it also has an impact on their future career and motivation, which will, of course, have a greater impact on our society. This research will be limited in the future. It only involved a small sample size (110 respondents). This means that the implication 
of the result is limited. Future research should include a more in-depth discussion involving a larger number of samples.

\section{REFERENCES}

B.Miles, M., Huberman, A. M., \& Saldana, J. (2014). Qualitative Data Analysis - Matthew B. Miles, A. Michael Huberman, Johnny Saldaña - Google Books. In Sage Publications.

Creswell, J. W. (2013). 6: Choosing Among Five Approaches (Cresswell). In Qualitative Inquiry \& Research Design: Choosing Among Five Approaches.

Gugus Tugas Percepatan Penanganan COVID-19 RI. (2020). Peta Sebaran I Gugus Tugas Percepatan Penanganan COVID-19. Covid19.Go.Id.

Hasan, M., Bijoy, M. H. I., \& Akhi, S. A. (2020). Refute the Decision of Auto-Promotion and Real Facts of Digital Online Classes during the Pandemic in Bangladesh. Proceedings of IEEE International Conference on Advent Trends in Multidisciplinary Research and Innovation, ICATMRI 2020. https://doi.org/10.1109/ICATMRI5 1801.2020.9398326

Irawan, A. W., Dwisona, D., \& Lestari, M. (2020). Psychological Impacts of Students on Online Learning During the Pandemic COVID-19. KONSELI: Jurnal Bimbingan Dan Konseling (E-Journal). https://doi.org/10.24042/kons.v7i 1.6389

Joseph, S. (2020). Isolation and Mental Health: The Psychological Impact of COVID-19 Lockdown on Children. Mukt Shabd Journal.

OECD. (2020). The impact of COVID-19 on education: Insights from education at a glance 2020. In OECD Journal: Economic Studies.

Ramatillah, D. L., \& Isnaini, S. (2021). Treatment profiles and clinical outcomes of COVID-19 patients at private hospital in Jakarta. PLOS ONE.

https://doi.org/10.1371/journal.po ne.0250147

Syahputri, V. N., Rahma, E. A., Setiyana, R., Diana, S., \& Parlindungan, F. (2020). Online learning drawbacks during the Covid-19 pandemic: A psychological perspective. EnJourMe (English Journal of Merdeka) : Culture, Language, and Teaching of English. https://doi.org/10.26905/enjourm e.v5i2.5005

Wiles, G. (2020, July 30). Students share impact of online classes on their mental health. The State News. Retrieved from: https://statenews.com/article/202 0/07/students-share-impact-ofonline classes-on-their-mental health?ct=content_open\&cv=cbox latest 
sScience Humanity gournal

Vol. 2 No. 1 November 2021 elSSN 2747-1926 pISSN 2774-1605 